\title{
The Unitarian's Service Committee Marseille Office and the American networks to aid Spanish refugees. (1940-1943)
}

\author{
Aurelio Velázquez-Hernández \\ e-mail: aurevh@gmail.com \\ ORCID iD: http://orcid.org/0000-0003-0001-4595
}

\begin{abstract}
Submitted: 18 May 2018. Accepted: 26 March 2019
ABSTRACT: The Unitarian Service Committee was one of the most important US aid agencies involved in assisting refugees in the World War II context. In the article I analyse the origins of its action in Europe, focusing on a practically unknown aspect which as its intervention in favour of Spanish Republicans who had fled from Spain and the threat of Francoism in 1939. The Unitarian Service Committee (USC) began its operations in the spring of 1940 and an office of the Unitarian Service Committee would be established in Marseilles in 1941. From this office active work was focused mainly on medical help for the camp inmates in the south of France. The USC had an aid program dedicated exclusively to the Spanish refugees. This program was supported by funding from another American organization, the Joint Antifascist Refugee Committee closely linked to socialist and communist circles and whose chairman, Edward Barsky, was a former international Brigadier who had participated in the Spanish Civil War. I will analyse the links between these two organizations and their connections with international relief networks.
\end{abstract}

KEYWORDS: Humanitarian action; International aid networks; Second World War; France; Spanish republican exile.

Citation / Cómo citar este artículo: Velázquez-Hernández, Aurelio (2019) “The Unitarian’s Service Committee Marseille Office and the American networks to aid Spanish refugees. (1940-1943)". Culture \& History Digital Journal, 8 (2): e021. https://doi.org/10.3989/chdj.2019.021

RESUMEN: La oficina de Marsella del Unitarian Service Committee y las redes americanas de ayuda a los españoles refugiados (1940-1943).- El Unitarian Service Committee (USC) fue una de los organismos de ayuda americanos más relevantes de cuantos participaron en la asistencia a los refugiados durante la Segunda Guerra Mundial. En el texto analizamos los orígenes de su labor en Europa centrándonos en un aspecto prácticamente desconocido de su actuación como fue la asistencia a los republicanos españoles que marcharon al exilio huyendo del franquismo. El Unitarian Service Committee (USC) fue fundado en la primavera de 1940 y desde muy pronto instaló una delegación en Marsella. Desde esta oficina desarrollaron fundamentalmente una activa labor en la atención médico-sanitaria a los internos de los campos del sur de Francia. El USC tuvo un programa de ayudas exclusivamente dedicado a la asistencia a los republicanos españoles financiado íntegramente por otro organismo de ayuda americano, el Joint Anti Fascit Refuggee Committee. Esta organización, presidida por un veterano de las Brigadas Internacionales, el Dr. Edward Barsky se encontraba estrechamente vinculada con sectores del socialismo y comunismo americano e internacional. Analizaremos los vínculos entre ambas organizaciones y sus conexiones con las redes internacionales de ayuda.

PALABRAS CLAVE: Ayuda humanitaria; Redes internacionales de ayuda; Segunda Guerra Mundial; Francia; Exilio Republicano español.

Copyright: (C) 2019 CSIC. This is an open-access article distributed under the terms of the Creative Commons Attribution 4.0 International (CC BY 4.0) License. 
The history of the humanitarian action as a social movement has barely started to develop in recent decades and there are still many aspects on which there still remains much work to be done ${ }^{1}$. In this respect, I regard as worthy of particular attention, not only the action carried out by isolated agents, but also the links established between different groups and the common projects undertaken. The Second World War was a key period for the development of humanitarianism, as the humanitarian disaster resulting from this conflict was of such colossal dimensions that it required the creation of large consortia that joined forces in favour of victims the war victims and of political and racial violence. Transnational collaborative networks were forged that made it possible to increase the scale of the projects undertaken.

One of the organizations that best knew how to adapt to this situation and which best functioned as intermediaries and generators of these transnational networks was The Unitarian Service Committee (USC) (Genizi, 1987: 261-276; Di Figlia, 1990; Lewis, 1952; Subak, 2010). It is a charitable organization dependent on the American Unitarian Church that has its headquarters in the city of Boston. This committee was officially founded in May 1940, with the war in full sway. Its founder was Robert Dexter, a social worker and head of the Departments of Social and International Relations of the American Unitarian Association who, during a trip to Prague with his family in 1938, came into contact with the problem of the refugees and began to develop the idea of establishing an aid agency to address such a pressing problem (Subak, 2010: 26) For its organization he followed the example of the American Friends Service Committee ${ }^{2}$ of the American Quakers, an entity for which both Robert Dexter and several of the unit leaders declared their admiration. Nevertheless, the character of this new organism, according to the religious philosophy of the Unitarians, was very different from that of the Quakers. In the words of one of the main leaders of this new organization, Charles Joy:

I consider our policy as a service organization differs radically from the Quaker policy, in that we are not trying to help both friend and foe alike without distinction. I conceive our work to be strengthening of the side which we believe to be right. That means that I consider our committee to be an ally of all the forces of democracy and freedom and righteousness, and opposed to the subversive forces that would destroy our most precious heritage. ${ }^{3}$

This special sensitivity of the Unitarians that prevented them from remaining neutral to the conflict they were witnessing and forced them to position themselves in favour of the defenders of democracy and freedom was what brought them closer to one of the neediest human groups of those times: the Spanish republicans. The Unitarian Service Committee was one of the few religious organizations that tried to alleviate the situation of these exiles, on the contrary, other American aid agencies, as well as the government of that country, suffered what Aurora Bosch would aptly call "fear of democracy" (Bosch,
2012) and did not want to get involved with elements considered dangerous or undesirable because of their supposed links with communism.

In the next few pages I will try to approach the actions of this organization in favour of Spanish Republicans in a particularly complex context, namely that of Vichy France. The humanitarian action in favour of the Spanish exiles is a field of study that has only just begun to develop in recent years and we know next to nothing about the participation of the North American organizations in this labour. I shall pay particular attention to the analysis of partnerships established with other aid agencies and to the establishment of transnational collaborative networks and their results.

\section{THE USC'S FIRST STEPS IN EUROPE}

One of the first initiatives undertaken by the Unitarian Service Committee (USC) after its foundation was to establish an office in Europe, in Paris. This company would be entrusted to two of its most efficient social workers, a young unitary minister from Wellesley Hills (Massachusetts) named Waitstill Sharp and his wife Martha Sharp Cogan. ${ }^{4}$ These USC agents planned to travel to Paris on June 15,1940 . However, on the $14^{\text {th }}$, German armies entered the French capital. They had to change plans completely on the spur of the moment and on June $20^{\text {th }}$ landed in Lisbon. The Sharps decided to move the project to Portugal, which had become a strategic point as it was the only port open for the departure of refugees throughout the continent ${ }^{5}$, thus establishing in Lisbon the USC's first permanent office in Europe. ${ }^{6}$

The priority of the new organism was the emigration to America of European refugees, so when the situation stabilized, the Sharps travelled from Lisbon to Marseilles. There they came into contact with other agents of American organisms who were helping in the area. Among them, Donald and Helen Lowrie of the World YMCA (Young Men Christian Association) (Lowrie, 1963). Together they organized a milk distribution project for refugee children in some departments of Southern France. ${ }^{7}$ The Sharps were responsible for obtaining milk powder in Lisbon and Donald Lowrie for its distribution in the Pau area, which was in desperate need, as the Red Cross food distribution programme was not applied in this department, because it was partially occupied by the Germans. ${ }^{8}$ USC statistics estimate that until October that year, about 800 children benefited from this programme. In addition, the Unitarian initiative made the International Committee of the Red Cross in Geneva aware of this problem by organizing the shipment of milk cargoes to other French departments with the same needs. ${ }^{9}$

In August 1940, while Martha Sharp was in the South of France engaged in the milk distribution programme, Waitsthill Sharp was visited in Lisbon by Varian Fry, a young American journalist who stopped in the Portuguese capital on the way to Marseilles to ensure the representation in the unoccupied zone of the Emergency Rescue Committee. ${ }^{10}$ In France this organism would operate under 
a less offensive name for the collaborationist authorities: Centre Américain de Secours. Its aim was to seek emigration to the United States of the most prominent members of European culture who were directly threatened. Given the coincidence of interests between the two organizations, Fry and Sharp would reach an agreement to collaborate, so that the USC would be responsible in Lisbon for the refugees that the ERC managed to bring there. In exchange, Fry would oversee the USC's milk distribution programme in Marseilles (Suback, 2010: 36-39). Thanks to this collaboration, during the next few years several hundred-according to some sources up to two thousandprominent Jewish and anti-fascist intellectuals were able to find sanctuary in America, among them such prominent individuals as Hannah Arendt, Victor Brauner, André Breton, Marcel Duchamp, Heinrich Ehrmann, André Gide, Max Ernst, Lion Feuchtwanger, Jacques Lipchitz, Heinrich Mann, André Masson, Anna Seghers and Victor Serge, to give just some examples from a long list.

In September 1940, Dr. Charles R. Joy arrived in Lisbon to work with the Sharps. Joy had been a unitary minister for many years, and had served the army YMCA in France for two years as divisional secretary and regional director, being decorated with the commemorative medal of the Great War. While the Sharps were in France, Waitstill collaborating with Varian Fry in the evacuation of eminent intellectuals and Martha, along with the Lowrie in a Children's Rescue Programme, Charles Joy took charge of the Lisbon office.

In November 1940, Donald Lowrie tried to organise a meeting for the coordination of the activities of the various aid agencies operating in the South of France. Twenty-five of the main aid agencies working in the South of France met at Nîmes. Together with the USC and the YMCA, there were three Red Cross organizations, seven Jewish organizations, the International Migration Service or the American Friend Service Committee (AFSC), among others. They decided to establish a coordination mechanism that would be known as the "Comité de Coordination des Euvres d'Assistance dans les Camps" or more commonly: "The Nîmes Committee" since monthly meetings were established in that city. ${ }^{11}$ This committee was dedicated to preparing reports on conditions in refugee camps. These reports were delivered directly to the Camp Inspector of the Camps of the Vichy Government, André Jean-Faure, who participated in the meetings, perhaps as a concession to the public opinion, or perhaps simply to control the activities of this committee (Ryan, 1996: 149-150). But the most relevant aspect of this committee was its attempt to coordinate the activities of the different agencies that worked in the unoccupied zone of France. So the tasks of each were allocated. Thus, while other organizations such as AFSC, OSE or Swiss Relief were in charge of food, the Emergency Rescue Committee, or the HICEM focused on evacuation, the work of the Unitarian, together with the different institutions of the Red Cross, was focused on medical care and distribution of medicines, mainly for those interned in the camps of Southern France.
On September 28, 1940, Waitstill Sharp returned to the United States with the distinguished German novelist Lion Feuchtwanger, who only managed to escape from Lisbon in disguise by posing as Martha Sharp. At the end of that year, Martha Sharp followed her husband after completing her project to remove 28 children (Czech, German, Austrian and French) from France and install them in America in foster homes. Charles Joy would then be in charge of the entire USC project in Europe. ${ }^{12}$

\section{THE MARSEILLES OFFICE AND THE WORK IN VICHY FRANCE, 1941-1942}

Charles Joy argued that it was better to maintain a policy of aid to refugees in the camps, rather than investing in their transfer to America. He stated to the members of the USC Board that "it is better to keep 6,000 children alive in France than to take a hundred or so to America."13 The Boston headquarters agrees with Joy on the idea of expanding work in the camps, so they decided to open a new office in the Vichy France. ${ }^{14}$ In France is hired to lead as a director, Noel Field, a US Quaker recommended by Donald Lowrie, who had worked in international relations and for the refugee programme of the Nations. His wife Herta Field is also hired as an assistant. ${ }^{15}$

The new office was set up in Marseilles, at Rue Fortia No. 15. Noel Field took over the management, while Herta was in charge of legal matters (visa application and assisting immigration procedures, etc.). As staff for the new office, Charles Joy hired George Raptopoulos as a treasurer, a Greek, born in Constantinople, who spoke four languages and had been for twelve years the head of exchange of the Ottoman Bank in Marseilles. They also had the services of a Spaniard, Josep Trias, who was a specialist in employment, had been director of the National Catholic Committee until June 1940 and collaborated with the French labour Minister. Walter Meyerhof was also recruited as assistant of the director and had the sporadic collaboration of several workers in the YMCA office. The maintenance of these personnel represented a cost of about $\$ 200.00$ per month, although only $\$ 60$ would appear in the books as salaries, the rest was considered aid.

From the new office in Marseilles, they soon began to work on a plan to try to bring medical support to the concentration camps in Southern France. To this end, they coordinated with the League of Red Cross Societies and the International Committee of the Red Cross (ICRC) in Geneva and prepared an initial budget of about $\$ 10,000 .{ }^{16}$ In addition, Charles Joy worked on the creation of a service to send food parcels and toiletries to refugees in these camps. Goods could be bought in Portugal and packages of up to five hundred grams sent by certified mail and up to five kilogrammes by regular mail at a much reduced cost, in this way making it possible to deliver aid to specific individuals. ${ }^{17}$

In the following months, Charles Joy would return to Lisbon, leaving Noel Field in charge of the Marseilles office. According to the Committee of Nîmes, the work of 
this office focused on medical care for inmates of the camps of Gurs, Rivesaltes, Argeles, Le Vernet, Recebodou, Noe, Riecreux, Bompard and Les Mille. Subsequently, drugs were also sent to the labour camps in which the Foreign Workers' Companies were located, and where in many cases their situation was as bad as or worse than that of the inmates in internment camps, which greatly increased the office's budget and workload. ${ }^{18}$ Field began to collaborate with Joseph Weill, director of Jewish Children's Aid Society (known as OSE due to its acronym in French: Euvre de secours aux enfants) (Zeitoun, 1990). Both organisms came to share their facilities in Marseilles. Weill introduced Field to physiologist René Zimmer, who would be the director of the Unitarian's medical aid programme in France. For this labour, Zimmer counted on the collaboration of Zina Minor, a Russian doctor, who could not practice medicine in France because she was a Jew (Subak, 2010:86-87).

In order to obtain medicine there was close collaboration with the ICRC and the League of Red Cross Societies, which sent supplies and food supplements to the Marseilles office from Switzerland. Noel Field and his wife made repeated trips to Switzerland from Geneva to arrange shipment of these supplies and the location of some medicines that could not be obtained in France, as well as items such as glass eyes, dentures, bandages for hernias, or orthopaedic limbs. ${ }^{19}$ The Fields had their residence officially established in Switzerland in case that war evolved in such a way that they would be forced to take refuge in that country. Travelling to and from Switzerland was so frequent that in July 1942 Noel Field managed to get the YMCA to donate a space in their offices in Geneva at the Palais Wilson, to have a postal address in Switzerland and to carry out his business, just as he also had the services of a voluntary secretary. ${ }^{20}$ The USC's central pharmacy kept a stock of numerous medicines, as well as vitamins and hormone solutions that could not easily be found in France. From this office the medicines were distributed to the camps. Dr. Zimmer was in charge of visiting and conducting studies on supply needs in coordination with KZ- doctors. ${ }^{21}$

In April 1941, it was finally decided to establish a clinic in Marseilles in collaboration with the OSE. It was a social and health centre, since the OSE workers were responsible for social care, while the doctors contracted by the USC were concerned with health issues. Together with Dr. Zimmer, who was also in charge of the clinic, the health staff dependent on the Marseilles office came to number some fifty members, including physiologists, surgeons, dentists, nurses and specialists from the different branches of medicine. This clinic basically attended to the inmates from nearby camps who were sent there, as well as all those refugees residing in the surroundings of Marseilles.

Paediatric consultations were, of course, an important part of the service, given the harsh conditions in which those children had to grow, many of whom were even born in the camps themselves, many others orphans or whose parents in prison or other internment camps. Nutri- tional supplements were provided for the children, as well as a special kind of gymnastics to avoid bone deformation and weakness resulting from dietary deficiencies. Children particularly affected especially by these deformities were offered massages and re-education classes, in the same way ultraviolet light treatment was introduced to combat cases of rickets. The services offered by the clinic were completely free and all that was required was a letter of recommendation from doctors in the camps or from some aid agency "declaring that they were bona fide refugees or internees without private means at their disposal". 22

The USC invested large amounts in technical equipment for the clinic in Marseilles, as well as for the camp doctors, who were provided with, among other things, Xray devices, surgical supplies and dental services. In the same manner, a small hospital was also opened and maintained in Toulouse. An old school donated free of charge by French authorities was utilized. There were approximately forty beds and it was used for hospitalisation and surgical treatment of inmates from neighbouring camps. It was fully equipped with an operating theatre X-ray machine and a biological laboratory. However, this hospital was available for long as the building was requisitioned by the French government for the war wounded, but the personnel and all equipment were transferred to the nearby camp of Récébédou, which was transformed into a hospital camp for refugees suffering from chronic or acute diseases. ${ }^{23}$ Despite the fact that the USC budget for this project was quite limited, from November 1941 onwards it benefitted from the economic collaboration of the Jewish Joint Distribution Committee (Suback, 2010: 123-124).

Meanwhile, at the Marseilles office they also became aware that the situation of minors in internment camps was not only worrying from a health perspective but also because of the total absence of education. An USC report noted that: "the complete lack of scholastic or religious education, enforced idleness and lack of discipline created in these children very alarming moral and mental conditions." 24 In order to alleviate this situation, a series of kindergartens were set up in Rivesaltes, which was one of the camps with the largest number of minors, about four thousand according to the figures managed by the Unitarian. In these schools, not only instruction was provided, but also entertainment. To this end, a puppet theatre and a scouting group were set up. Thanks to the scouting group the children were able to go on excursions in the countryside and, furthermore, contact was made with the Scout movement in France and Switzerland, which sent some gifts to the Rivesaltes group. ${ }^{25}$ In addition, a small school was set up in the Marseilles district of Bombard, which was attended by sixty children, children of refugees who were awaiting re-emigration to another country. ${ }^{26}$

Alongside the medical and educational programmes, the Fields continued with Case Work which involved greater complexity. It was a question of providing assistance and advice to the numerous refugees or internees, who required individual attention due to the seriousness 
of their situation, due to their exceptional merits, or to the fact that they had been referred by the Boston headquarters or the Lisbon offices. With respect to these individual cases, on some occasions material help was provided, others obtained support was provided via mediation with the French authorities, while others were assisted in their emigration to America. ${ }^{27}$

The emigration programme, which had given rise to the USC, continued to be active and in this regard it collaborated actively with the Nîmes Committee. However, the war context made the contracting of ships very difficult. Consequently, in the United States, Unitarian members tried to pressure the government to unblock the situation. In addition, the Fields' multiple occupations in the field of medical care and education led them, to a large extent, to neglect the issue of emigration. This is perhaps partly due to the aforementioned difficulties, but also because there were other agencies in France that were responsible, to a greater or lesser extent, for these tasks, such as the Emergency Rescue Committee, the American Friends Service Committee, the YMCA, or the International Migration Service, as well as various Jewish aid organizations (HICEM, OSE or the Joint Distribution Committee). The emigration programme brought problems. It was very complex work that required great dedication, and involved significant amounts of financial and human resources. The cases of politicians, artists and intellectuals, who were of more interest to the Unitarians, attracted the attention of the French authorities. As in most cases, it was necessary to resort to methods of dubious legality in order to get these people out of the country. This activity involved running evident risks that could jeopardize the remaining aid programmes developed in France. ${ }^{28}$

As I have indicated, collaboration between different organisms which acted in France at that time was very close. Through the Coordination Committee of Nîmes, they divided the activities so that each of them specialized in a different field. During the Sharps' time in France, collaboration with the YMCA was very close, with several common projects established. Yet, when Noel Field took over the management, close contact was established with the OSE, with which even the Marseilles offices and clinic were shared. At the same time, specific collaborations were also carried out with other organizations, thus for example, in mid1942, sixteen Spanish minors, included by Quakers in a voyage financed by the OSE to the United States, were examined and vaccinated at the Unitarian clinic in Marseilles. These kinds of activities and interagency service exchanges were constant at that time..$^{29}$

\section{COLLABORATION WITH THE JAFRC AND AID TO SPANISH REPUBLICANS}

The Unitarian did not only obtain its funding from the donations of the Unitarian Church or individual Unitarians, but, fundamentally, through the contributions that other organizations channelled through the USC projects. In this sense, the most relevant donors were the Congregational Christian Service Committee, the American Re- lief for France and the Joint Anti-Fascist Refugee Committee (JAFRC).

In the case of Spanish Republicans, most of the funds employed by the Unitarian in their aid came from this latter agency, the JAFRC. This agency, chaired by the former international brigadier Edward Barsky (Deery, 2014: 11-39; Barsky, 2008: 52-59), emerged in 1940 when it split off from the largest aid movement of the United States to the Spanish Republic, the Medical Bureau \& North American Committee to Aid Spanish Democracy, which after the Republican defeat in April 1939 had made its most notable activity the Spanish Refugee Relief Campaign $^{30}$. The ongoing tension in this organization between the liberal and socialist groups and philo-communists was exacerbated with the beginning of the war in Europe and stances regarding the French government's treatment of the Spanish republicans in its territory. At a Pan-American conference held in Mexico City in February 1940, a resolution condemning the French government was approved, which, ultimately, broke the unity of the agency. On April 14, 1940, the Communist and related elements formed their own organization, the United American Spanish Aid Committee (UASAC), although it would be much better known by the name acquired in 1942: the Joint Antifascist Refugee Committee (JAFRC). To simplify, I shall refer to it in the latter form, with this last denomination despite the anachronism when referring to is activities prior to 1942 (Smith, 2013: 105-108).

The first contacts between the Unitarian and the JAFRC (by then UASAC) were made in September 1941, when the body chaired by Edward Barsky intended to use the aid package programme implemented by the Unitarians to send aid packages to some Spanish inmates in the internment camps in Southern France and also to other prisoners in Spanish prisons. ${ }^{31}$ From that moment on, institutional collaboration between both organizations was established and, from end of 1941 onwards, several items were sent by post to Spaniards in the French camps. Meanwhile, the USC, which had implemented this system for the camps in the South of France, but had no plans to use it in Spain, also sent from Lisbon small packages with food for Spanish and foreign prisoners, belonging to the former International Brigades, in Spanish prisons and prison camps like Miranda de Ebro.

In July 1941, there was much correspondence between both organisms with regard to the situation of the Spanish in France. There was particular concern vis-à-vis the situation of the Spaniards in the Argelès-sur-Mer camps who, according to the Unitarian reports, still numbered about 12,000 and had spent about three years in deplorable conditions in what Charles Joy defined as: "the worst of all camps". In addition to this, many international ex-brigadiers had been deported from these camps to the North of Africa and there was no accurate information regarding their circumstances. Charles Joy expressed deep concern for this group because for him: "The International Brigade is the finest group of men, from the point of view of morale, that I have encountered anywhere in my work overseas". The Barsky Committee was interest- 
ed in sending a delegate to France and North Africa to study the situation and Joy himself would offer to serve as a delegate as he was thinking of studying these cases on his next return to Europe. ${ }^{32}$

Finally, both agencies would reach a broader partnership agreement. In the first place, Charles Joy also pledged to report to Barsky's agency on his study of refugees, with special interest in the Spanish refugees and international brigadiers, while in exchange JAFRC would contribute \$ 500 to cover part of the expenses of this project. But the most important part of this agreement would not be this, but the fact that both bodies consolidated their institutional relationship and, looking ahead to future aid that they intended to offer in France to Spanish refugees, they hired a new employee for the USC offices in Marseilles. The new employee would be dedicated exclusively to providing aid to the Spanish and his salary, although he would be part of the Unitarian staff, would be paid exclusively by JAFRC. The USC also issued an undertaking to explore the possibilities of helping prisoners in Spanish prisons and to devise plans for the individual evacuation of Spaniards and international brigadiers that would only be carried out after a detailed study of the possibilities. For its part, it was understood that Barsky's agency would utilise every means at its disposal to collaborate in providing medical aid and other supplies to help Spanish refugees in France. ${ }^{33}$

The USC was aware of the fact that there was tremendous animosity and prejudice against the Spanish republicans on the part of the collaborationist Vichy authorities. But, to further complicate the situation, Barsky's agency, from the very moment of its formation, had been conducting a campaign of attacks on the French government for the treatment offered to the Spaniards. Therefore, in order not to prejudice these activities, as well as the rest of the Unitarian projects in France, it was decided not to publicise the agreement. Discretion was fundamental, so a Spanish refugee with a Cuban passport, who had already worked for the Cuban consulate in the country, Professor Llanos, was chosen to work in the Marseilles office. ${ }^{34} \mathrm{He}$ would join the USC office in November 1941, with a monthly salary of $\$ 25$ dollars that was paid by the JAFRC. In the same way, additional amounts were also sent by this agency from New York for inspection expenses in the camps and to finance all the aid that could be offered from Marseilles to the Spaniards. ${ }^{35}$

In practical terms, the first activity carried out by Professor Llanos, in the Unitarian office in Marseilles, was the completion of a report on the situation of Spanish Republicans in France. In this report, somewhat partial and not very precise, especially with regard to the figures, it was noted that there were still approximately 120,000 Spanish Republicans in France, whose situation was especially difficult. After the French debacle of June of 1940, they were inundated by a flood of French refugees who fled to the south of the country, saturating the towns in the area. Spaniards who were not familiar with the language, without family networks or friends, were particularly vulnerable. After the collapse of the public institutions, they found themselves without any official help. Llanos, in col- laboration with the USC Marseilles office, drew up a working plan to assist Spanish refugees in France. It was necessary to treat as a priority those who suffered a more precarious situation, such as refugees in camps and labour companies. Therefore, first of all he recommended continuing with the efforts that the USC was already making in clinics, health, medical, surgical and dental care, as well as improving the Rivesaltes hospital. Along the same lines, he supported the increase of the system of shipment of packages with food and, in addition, he also encouraged collaboration with the League of Mutilated and Disabled in the creation of an aid programme for these people, offering them special medicines and artificial limbs. Each of the prostheses could be purchased for a cost of eight hundred to one thousand francs, so fifty maimed could be treated per month at a cost of fifty thousand francs. Finally, there was a proposal to create a residence for minors so that they could leave the camps and lead a normal and healthy life. This was undoubtedly the most ambitious project because, for a colony of around two hundred minors, the cost would be much higher, about one hundred thousand francs for the installation plus another six hundred thousand annually for its maintenance. ${ }^{36}$

Applying the principles established in this aid plan, from November 1941 to February 1942 the Barsky committee issued several transfers to the value of $\$ 4,500$ to be used in the purchase and distribution of food packages in France. In February 1942, they were forced to suspend the package delivery program because of the United States Treasury Department suspended their license for this activity. ${ }^{37}$ On the other hand, in the year between November 1941, when Professor Llanos started working in the Marseilles office, and November 1942, when the definitive occupation of Southern France by the German army took place, $\$ 10,150$ was sent by the office to provide aid for the Spanish. ${ }^{38}$

Much of this money was not sent to Marseilles through the USC, but through the Mexican consulate in Marseilles. The Mexican consul, Gilberto Bosques, had established with the financing of the Spanish aid agencies in Mexico an aid plan in Marseilles for Spanish refugees. Two châteaux were rented to be used as sanctuaries and a legal aid service for extradition cases was set up. ${ }^{39}$ However, USC leaders were not convinced by this system of channelling the money through the Mexican embassy, because they did not fully trust the conduct of the Mexican officials. For Charles Joy:

Mr. Bosques is a good man but the Mexican officials in France have badly muffed a splendid opportunity. Hundreds of visas for Mexico have long been available but the report I get is that the Mexican officials are playing politics in France and the result is interminable delays, and in the end sacrifice or opportunities to escape. This is not only my opinion but the opinion I believe of all the relief organizations. ${ }^{40}$

With the amounts sent to the Marseilles office, Llanos concentrated above all on implementing the plan for the care of the maimed and disabled. For this purpose, a fund 
for orthopaedic aid to Spaniards of 50,000 francs was created, as planned. He began by developing, in collaboration with the League of Maimed and Disabled, an extensive list of Spaniards in need of orthopaedic limbs. First to be helped was a man who had lost both legs for whom a cart was purchased so he could get out of the bed to which he was confined. After that, a system was created through which an interview and a medical examination of the candidates were carried out, with measurements and photographs taken of their stumps. However, it was extremely difficult to find orthopaedic limbs in France, so they had to resort to importing them from Switzerland. ${ }^{41}$

Attempts were also made to establish residence for Spanish children. Even the USC offered to contribute five hundred dollars a month to JAFRC to get some 200 Spanish children out of the camps. ${ }^{42}$ However, the plan was finally shelved due to the expense and the fact that there were already other organizations, such as the Quakers and the Secours Suisse, that had more experience in this field and sufficient funds for maintenance, so the decision was taken to continue with the work with which they were familiar, in other words, medical assistance. In this respect, a report by Noel Field stated that it would be more appropriate to further investigate the idea of a nursing home for Spaniards in which children could also stay. ${ }^{43}$

This approach coincided with the project that Gilberto Bosques was implementing to create residences for Spaniards in the Marseilles area. And therefore, they tried to unite both projects by coordinating their efforts. So they decided to move forty Spanish children from the Rivesaltes camp to one of the Chateaux organized by the Mexicans. In fact, to prepare this transfer they donated some school and medical supplies. However, the living conditions for the hundreds of Spaniards housed in the two residences created by Bosques did not quite convince the USC leaders, who noted in one of their reports:

Conditions are a little better than in the camps and refuges, but none the less are still unsatisfactory, for they are not permitted to leave the place without a written permission. Their good is inferior to the essential minimum required and in general they lack everything except a roof and food. ${ }^{44}$

Finally, this new project was also abandoned because as the transfer approached, the situation in the Rivesaltes camp, where the minors came from, had improved considerably, partly due to the considerable reduction in the number of internees, and partly due to the great improvements in food quality thanks to the Secours Suisse aid. Also, at that time, the Quakers received funds to attend to Spanish children in this camp, so it did not make much sense to continue with the relocation. ${ }^{45}$

\section{TOTAL OCCUPATION AND THE END OF ACTIVITIES IN MARSEILLES}

At the beginning of November 1942, the Allies landed in North Africa and, to protect its southern flank, on November 11 Germany ordered the occupation of the area of
France controlled by the Vichy government. Noel and Herta Field were informed of the German invasion by a telephone call and abandoned everything, including all their personal possessions, taking the last train for civilians, departing from Marseilles at midnight. They arrived in Switzerland literally seconds before the Gestapo and after crossing the border settled safely in Geneva. There they continued to develop some activities in favour of the refugees from France that were residing in Switzerland. ${ }^{46}$ With regard to the Marseilles office, after the departure of the Fields it was abandoned, but Dr. Zimmer managed to maintain the clinic and the rest of the medical services operational. He enjoyed the protection of the local authorities and, in mid-January 1943, the clinic reopened its doors, changing its name to a much more aseptic one: Centre de dépistage et de prophylaxie. ${ }^{47}$ The social service offered thanks to OSE disappeared in practice, with the medical staff reduced to a minimum. Dr. Zimmer went on to take charge of the entire medical office, assisted by a nurse, while the dental clinic was in the hands of a single dentist and his nurse. As administrative staff one of the secretaries at the USC office in Marseilles was relocated as receptionist at the clinic, as well as a delivery boy who also previously held that role for the Fields. ${ }^{48}$ After the German occupation, Gilberto Bosques was arrested and the Mexican consulate closed. Many of the Spanish Republicans in the area who had benefited from the Mexican initiatives then went in search of help to the clinic governed by Zimmer. Despite the fact that according to USC memoirs this clinic managed to survive without contact or foreign funding of any kind, we know that they managed to communicate indirectly through the International Red Cross and the confidential channels of the American intelligence services, the Office of Strategic Services (OSS) that were also used to send funds. Furthermore, it was also able to obtain some contributions from the French Red Cross and the Service Social D'Aide aux Émigrants (SSAE). René Zimmer, as a member of the Committee of Nîmes, could move around the area, enter the camps and perform aid work, so he also entered the clandestine networks of the OSS, contacting and financing the resistance groups (Suback, 2010: 163-165). ${ }^{49}$ Thus, during the two years of German occupation they were able to continue, at a lower level, the projects undertaken in Marseilles until February 1944, when Dr. Zimmer had to flee and hide from the imminent danger of being arrested by the Gestapo. Thus ended the aid activities of these organizations in Marseilles until the final liberation of France, just a few months later..$^{50}$

\section{FINAL THOUGHTS}

Throughout the text we have been disengaging the aid work carried out by the Unitarian Service Committee in France from its Marseilles office during the German occupation and the complex service network that was created to meet the needs of refugees in the South of France. We have seen how in many cases these networks of collaboration were established, not only in terms of shared 
interests, but also based on the personal relationships of their agents on the ground. In this respect, the importance of the initiative undertaken by Donal Lowrie at the end of 1940 that allowed the creation of the "Comité de Coordination des Euvres d'Asistance dans les Camps" or "Comité Nîmes" should be highlighted. It made possible a qualitative leap in the coordination of the agencies operating in the south of France, transcending occasional, short-term collaborations to establish an authentic distribution of functions that made solidarity efforts much more efficient.

Finally, I have focused on one of the threads of this extensive aid network and seen that there was a close relationship between the USC and the Barsky Committee for the benefit of Spanish Republicans during this first stage in occupied France. We have verified the Unitarian's reluctance to make public this connection with an organism/agency openly critical of the collaborationist government of Vichy and with close links to elements of a communist leaning. In fact, after the war, the JAFRC was closed down and its chief executives sentenced to prison terms by the Un-American Activities Committee, which led the Unitarian to face some legal difficulties (Deery, 2014: 11-39). However, the collaboration between the two agencies in Marseilles resulted in major investment in the programme of package delivery to Spaniards in the camps, as well as in an orthopaedic aid plan for the maimed and disabled. Finally, it should also be stressed that both agencies worked together on individual cases. There were numerous examples of the USC offering specific aid to Spanish Republicans thanks to the funds donated by the JAFRC and, thanks to these contributions, Spanish and former international brigadiers were introduced to the emigration programme. We have documentary evidence of, at least, forty-four Spaniards who were evacuated to America, at a time when, because of the war context, tickets were enormously difficult to obtain and enormously expensive. ${ }^{51}$

To conclude, I have considered fundamental perspective for the history of humanitarian action, namely the establishment of these transnational networks of solidarity during the Second World War. A theme about which, however, much remains to be discovered.

\section{ACKNOWLEDGEMENTS}

This article forms part of a project carried out thanks to the research programme: 'Ayuda humanitaria europea en Francia durante la Segunda Guerra Mundial' (European Humanitarian Aid in France during the Second World War); Reference: HAR2014-58043-P funded by Ministerio de Economía y Competitividad, Gobierno de España.

\section{NOTES}

1 As general humanitarian histories, see: Barnett (2013); Farré (2014); on the refugee issue: Skran (2011); Gatrell (2015); Reinisch (2008); Frank and Reinisch (2014).
2 Regarding this organization see: Pickett (1953); Schmitt (1997); Jones (1937); Kershner (1950). And on action of the British Quakers: Mendlesohn (2002).

3 "Letter from Charles Joy to Robert Dexter", Lisbon, 6 January 1941, Unitarian Service Committee Archives Andover-Harvard Theological Library, Harvard Divinity School, Harvard University (USCA), exp. bMS 16185/2 (4).

4 Martha and Waitstill Sharp already had experience in this kind of mission. In 1939 they were commissioned by the American Unitarian Association to work with the Czech refugees after the German annexation of the Sudetes and the subsequent occupation of Bohemia and Moravia. For information about the Sharps see their autobiographies edited by Ghanda DiFiglia: Sharp, (2016); Sharp Cogan (2016). There is also a documentary film: Burns and Joukowsky (2016). And a book derived from the film: Joukowsky (2016).

5 The ambiguous Portuguese neutrality in the world conflict attracted refugees from all over the continent who were trying to leave for America. See: Pimentel and Ninhos (2013). But Lisbon also became a focus of attraction for spies and the trade in looted art. See: Pimentel (2014); Fialho Brandão (2017: 566-587).

6 "Joy: USC report on our relief work", Lisbon, 30 April 1941, USCA, bMS 347/49 (8).

7 "Martha Sharp's Report on Milk Distribution", Lisbon, 17 October 1940, USCA, bMS 16135/3 (9).

8 "Letter from Helen \& Donald Lowrie to 'Friends", Marseille, 10 September 1940, USCA, bMS 16135/3 (9).

9 "Resume of the Relief Work in France, 1940-1943", Boston, 27 April 1944, USCA, bMS 16007/10 (1), pp. 27-32.

10 It was a New York-based agency formed by a group of American activists, including such illustrious members as John Dos Passos, Upton Sinclair, Dorothy Parker, and socialist politician Norman Thomas. About this agency and Varian Fry, see: Fry (1945), or the works of: Marino (1999); Isenberg (2005). There is also a TV film about his experience during the war with William Hurt as Varian Fry: Chetwynd (2001).

11 In spring 1942 this committee was composed by the following organizations: Americans Friends Service Committee, Amitié Chrétienne, Centre d'Aide Tchecolovaque, CIMADE (Group of Protestant organizations), Comité aux Réfugiés, Commission des Camps (Union générale des israélites de France), CroixRouge Française, Direction des Centres d'accueil, Eglise Catholique (Pére Arnou, abbé Lagarde, Abbé Glasberg), Eglise Protestante (Aumonerie: Pasteur Toureille), Fédération des Sociétés Juives, Fédération Protestante de France (Pasteur Boegner), Fonds Européen de Secours aus Etudiants, groupement d'Assistance aux Polonais, HICEM, Joint Distribution Service Committee, Scours Suisse, Service Social d'Aide aux Emigrants, Service Social pour les Exilés de Belgique, OSE, ORT, USC, YMCA, YWMCA, YMCA polonaise. "Compte rendu du voyage du Secrétaire Général de L'Union Internationale de Secours aux Enfants en France non Occupée", Geneva, 25 June 1942, Archive of International Committee of the Red Cross (ICRC), O CMS D-130, p. 5. An epigraph is also dedicated to this committee in Chibrac (2005: 169-195).

12 "Historical studies, James Ford Lewis, 1938-1949", Boston, 1967, USCA, bMS 161143 (33).

13 "Letter from Charles Joy to Marion Niles", Marseilles, 21 March 1941, USCA, bMS 347/49 (23), p. 9.

14 "Memorandum from Mr. Elliot to Mr. Dexter", Boston, 6 January 1941, USCA, bMS 16185/2 (16), p. 82.

15 Noel Fiel was the son of an American diplomat, born in London and raised in Switzerland. In 1924 he graduated in History, Economics and Government at Harvard University. He worked for a year as a social psychiatrist with prisoners in Massachusetts. Noel worked for the League of Nations on several disarmament commissions and, especially, formed part of the commission formed for the evacuation of international brigades in Spain between October 1938 and March 1939, so he was familiar with the French camps for Spanish refugees. His wife, Herta, was born in Germany but she was naturalized as an American in 1926. She always worked as her husband's assistant. 
After the war they would be accused of espionage by both the United States and the Eastern Bloc. See: Lewis (1965); Field and Field (1999).

16 "Letter from Robert Dexter to Ernest Swift, Boston, 22 January 1941, USCA, bMS 16185/2 (16), p. 65.

17 Until that time the USC had limited food shipments to France so as not to interfere in the British strategy of blockade of the continent, so before implementing this project sought the approval of the British government and the Secretary of State. See: "Letter from Seth Gano to Viscount Halifax, British ambassador in United States" and "Letter from Seth Gano to Cordell Hull", Boston, 7 February 1941, USCA, bMS 16185/2 (16), p. 60-61. The affirmative answers arrived 15 and 28 February. See: Idem, pp. 44-49.

18 "Confidential report for members of the Unitarian Service Committee by Howard Brooks", 1941, USCA, bMS 16007/10 (1), p. 34

19 "Reports of activities in Europe, USC, by Joy", Boston, 14 September 1942, USCA, bMS 347/49 (7), p. 7

20 "Excerpts from field reports", Marseilles, 24 July 1942, USCA, bMS 347/49 (6), p. 2.

21 Confidential report for members of the Unitarian Service Committee by Howard Brooks", 1941, USCA, bMS 16007/10 (1), p. 37. In a joint OSE and Unitarian project a "Hygiene Commission" was formed in four camps: Gurs, Rivesaltes, Récébédou and Les Milles. The doctors on this commission were in equal parts paid by the Unitarian and the OSE. See: "Excerpts from field reports", Marseilles, 24 July 1942, USCA, bMS $347 / 49$ (6), p. 6.

22 "Resume of the Relief Work in France, 1940-1943", Boston, 27 April 1944, USCA, bMS 16007/10 (1), p. 30.

23 "Rescue from starvation by Winfred Overholser", December 1942, bMS 16004/11 (14), p. 5. See also: "Field, Noel, USC report on work in France", Marseilles, 6 March 1942, USCA, bMS 347/49 (4), p. 7.

24 "Resume of the Relief Work in France, 1940-1943", Boston, 27 April 1944, USCA, bMS 16007/10 (1), p. 31.

25 "Field, Noel, USC report on work in France", Marseilles, 6 March 1942, USCA, bMS 347/49 (4), p. 9.

26 "Confidential report for members of the Unitarian Service Committee by Howard Brooks", 1941, USCA, bMS 16007/10 (1), p. 37.

27 "Aid to Children, Unitarian Clinic", Marseilles, May 1942, ICRC, O CMS B-027.

28 "Confidential report for members of the Unitarian Service Committee by Howard Brooks", 1941, USCA, bMS 16007/10 (1), p. 38 .

29 "Aid to Children, Unitarian Clinic", Marseilles, May 1942, ICRC, O CMS B-027.

30 About this organization and its evolution see: Del Rey García (1997, 89-114); Lear (2013: 65-81).

31 "Letter from Helen R. Bryan to Charles Joy", New York, 17 September 1941, USCA, bMS 16031/2 (1-2), p. 5

32 "Letter from Charles Joy to Helen Bryan", Boston, 23 July 1941, USCA, bMS 16031/2 (1-2), p. 78-80

33 "Letter from Charles Joy to Edward Barsky", Boston, 31 July 1941, USCA bMS 16031/2 (1-2), p.73-74.

34 "Letter from Charles Joy to Helen Bryan", Boston, 4 de enero de 1942, USCA, bMS 16031/2 (1-2), p. 31

35 "Letter from Charles Joy to Helen Bryan", Boston, 20 November 1941, USCA, bMS 16031/2 (1-2), p. 17.

36 "Report on the situation of Spanish refugees in France", Lisbon, 14 January 1941, USCA, bMS 16031/2 (1-2), pp. 43-49.

37 "Letter from Robert Dexter to Helen Bryan", Boston, 25 February 1942, USCA, bMS 16031/2 (1-2), p. 41.

38 The JAFRC had pledged to increase his monthly contribution, from November 1942, to $\$ 3,000$ dollars but the German occupation of the whole French territory forced suspension of these new payments. "Memorandum Joint Antifascism Committee", Boston, 17 November 1942, USCA, bMS 16031/2 (1-2), p. 74.

39 On Gilberto Bosques and his work in Marseilles see: Garay (1988); Malgat (2013); Behrens (2003: 147-166); Gleizer (2015: 54-76).
40 "Letter from Charles Joy to Helen Bryan", Boston, 20 October 1942, USCA, bMS 16031/2 (1-2), p. 75. This testimony corroborates the hypothesis put forward by Daniela Gleizer that, contrary to general opinion, from the Gilberto Bosques` Consulate in Marseilles there were enormous bureaucratic obstacles to the granting of visas to refugees. See Gleizer (2015: 54-76).

41 "Field, Noel, USC report on work in France", Marseilles, 6 March 1942, USCA, bMS 16007/9 (14), p. 11-13.

42 "Letter from Charles Joy to Helen Bryan", Boston, 4 January 1941, USCA, bMS 16031/2 (1-2), p. 31.

43 "Field, Noel, USC report on work in France", Marseilles, 6 March 1942, USCA, bMS 16007/9 (14), p. 11-13.

44 "Report on the situation of Spanish refugees in France", Lisbon, 14 January 1941, USCA, bMS 16031/2 (1-2), p. 45.

45 "Field, Noel, USC report on work in France", Marseilles, 6 March 1942, USCA, bMS $16007 / 9$ (14), p. 11-13.

46 "USC historical studies, James Ford Lewis, 1938-1949", Boston, 1967, bMS 16114/3 (33).

47 "Report of our activities during the German occupation of Marseilles (1942-1944)", Marseilles, 1945, USCA, bMS 16035/1 (4), p. 2-17.

48 "Lettre de René Zimer à Noel Field", Marseilles, 30 December 1942, ACICR, O CMS B-027.

49 During the occupation years the Clinic could be financed thanks to the funds available to the USC's Marseilles office and the considerable stock of medicines that the pharmacy had. Report of our activities during the German occupation of Marseilles (1942-1944)". Marseilles, 1945, USCA, bMS 16035/1 (4), p. 2-17.

50 "Dr. Zimmer's Escape by Charles Joy", Boston, USCA, bMS $347 / 29(55)$

51 The cost of tickets at that time used to exceed $\$ 500$ per person, that same amount could finance a considerable amount of activity in the camps in France. "Letter from Helen Bryan to Charles Joy", New York, 2 November 1942, bMS 16031/2 (1-2), p. 67.

\section{REFERENCES}

Barnett, Michael (2013) Empire of humanity: a history of humanitarianism. Cornell University Press, Ithaca (NY).

Barsky, Edward (2008) "Alguien tenía que ayudar". In: Contra el fascismo. Nueva York y la Guerra Civil Española, edited by Carroll, Peter N. and Fernandez, James D., Museum of the City of New York, NYU Press, New York: 52-59.

Behrens, Benedikt (2003) "El consulado general de México en Marsella bajo Gilberto Bosques y la huida del sur de Francia de exiliados germanoparlantes, 1940-1942", Tzintzun, Revista de Estudios Históricos, 37: 147-166.

Bosch, Aurora (2012) Miedo a la democracia: Estados Unidos ante la Segunda República y la guerra civil española. Crítica, Barcelona.

Burns, Ken and Joukowsky, Artemis (directors) (2016) Defying the Nazis: the Sharps'war, Documentary Film, Public Broadcasting Services, 2016.

Chetwynd, Lionel (director) (2001) Varian's War, Tv Film, Barwood Film's, Ardent Productions.

Chibrac, Lucienne (2005) Les pionnières du travail social auprès des étrangers: le service social d'aide aux émigrants, des origines à la Libération. Éditions de l'École Nationale de Santé publique, Rennes.

Deery, Phillip (2014) Red Apple: Communism and McCarthyism in Cold War New York. Fordham University Press, New York.

Del Rey García, Marta (1997) Stars for Spain: la guerra civil española en los Estados Unidos. Ediciós do Castro, Sada (La Coruña).

Di Figlia, Ghanda (1990) Roots and Visions: The First Fifty Years of the Unitarian Universalist Service Committee, Unitarian Universalist Service Committee, Boston.

Farré, Sébastien (2014) Colis de guerre. Secours alimentaire et organisations humanitaires (1914-1947). Presses Universitaires de Rennes, Rennes. 
Fialho Brandão, Inês (2017) “"What's in Lisbon?” Portuguese Sources in Nazi-era Provenance Research', Journal of Contemporary History, 52, 3: 566-587. doi: 10.1177/0022009416658699.

Field, Hermann and Field, Kate (1999) Trapped in the Cold War: The Ordeal of an American Family. Stanford University Press, Stanford (CA).

Frank, Matthew and Reinisch, Jessica (editors) (2014) "Refugees and the Nation-State in Europe, 1919-59", special issue, Journal of Contemporary History, 49, 3: 477-621. doi: $10.1177 / 0022009414529318$.

Fry, Varian (1945) Surrender on Demand, Random House, New York

Garay Arellano, Graciela de (1988) Gilberto Bosques: el oficio del gran negociador. Secretaria de Relaciones Exteriores, México.

Gatrell, Peter (2015) The Making of the Modern Refugee. Oxford University Press Oxford.

Genizi, Haim (1987) "Christian Charity: The Unitarian Service Committee's Relief Activities on Behalf of Refugees from Nazism, 1940-5", Holocaust Genocide Studies, 2, 2: 261-276. doi: $10.1093 / \mathrm{hgs} / 2.2 .261$

Gleizer, Daniela (2015) “Gilberto Bosques y el consulado de México en Marsella (1940-1942). La burocracia en tiempos de guerra", Estudios de Historia Moderna y Contemporánea de México, 49: 54-76. doi: 10.1016/j.ehmcm.2014.12.002.

Isenberg, Sheila (2005) A Hero of Our Own: The Story of Varian Fry. Random House, Bloomington, Indiana.

Jones, Mary Hoxie (1937) Swords into Ploughshares: An Account of the American Friends Sevie Committee, 1917-1937. The Macmillan Company, New York.

Joukowsky, Artemis (2016) Defying the Nazis: the Sharps'war, Boston (MA)

Kershner, Howard E. (1950) Quaker Service in Modern War. Prentice Hall, New York.

Lear, Walter J. (2013) "American Medical Support for Spanish Democracy, 1936-1938". In Comrades in Health: US Health Internationalists, Abroad and at Home, edited by Birn, AnneEmanuelle and Brown, Theodore M., Rutgers University Press, New Brunswick (NJ): 65-81.

Lewis, Flora (1965) Red Pawn: The story of Noel Field. Doubleday and Company, Garden City (NY).
Lewis, James Ford (1952) The Unitarian Service Committee, unpublished $\mathrm{PhD}$ thesis, University of California.

Lowrie, Donal A. (1963) The Hunted Children. W.W. Norton and Company, New York.

Malgat, Gérard (2013) Gilberto Bosques: la diplomacia al servicio de la libertad, Paris-Marsella (1939-1942). Vanilla Planifolia, CONACULTA, México.

Marino, Andy (1999) A quiet American: The Secret War of Varian Fry, St. Martin's Griffin, New York.

Mendlesohn, Farah (2002) Quaker Relief Work in the Spanish Civil War. Edwin Mellen Press, London.

Pickett, Clarence E. (1953) For More than Bread: An Autobiographical Account of Twenty-five Years with the AFSC. Little, Brown and Company, New York.

Pimentel, Irene (2014) Espiões em Portugal durante a II Guerra Mundial. Esfera dos libros, Lisboa.

Pimentel, Irene and Ninhos, Cláudia (2013) Salazar, Portugal e o Holocausto, Temas e Debates, Círculo de Leitores, Lisboa.

Reinisch Jessica (editor) (2008) "Relief in the Aftermath of War", special issue, Journal of Contemporary History, 43, 3: 371-551. doi: 10.1177/0022009408091819.

Ryan, Donna F. (1996) The Holocaust and Jews of Marseille: The Enforcement of Anti-Semitic Policies in Vichy France. University of Illinois Press, Urbana (IL).

Schmitt, Hans A. (1997) Quakers and Nazis, Inner light in Outer Darkness. University of Missouri Press, Columbia (MO).

Sharp Cogan, Martha (author); DiFiglia, Ghanda (editor) (2016) Church Mouse in the White House, Boston (MA).

Sharp, Waitstill (author); DiFiglia, Ghanda (editor) (2016) The Liberation of the Human Spirit, Boston, MA.

Skran, Claudena M. (2011) Refugees in inter-war Europe the emergence of a regime. Clarendon Press, Oxford.

Smith, Eric R. (2013) American Relief Aid and the Spanish Civil War, University of Missouri Press, Columbia (MO).

Subak, Susan Elisabeth (2010) Rescue and Flight. American relief workers who defied the Nazis, Nebraska University Press, Lincoln (Nebr)

Zeitoun, Sabine (1990) L'Oeuvre de Secours aux Enfants (O.S.E.) sous L'Occupation en France. L'Harmattan, Paris. 